\title{
Agricultural Development Policy of CornAgropolitan Programin Enhancing Farmers Revenuein Province Gorontalo
}

\author{
Djafar Ibrahim \\ Universitas Ichsan Gorontalo, Indonesia
}

\begin{abstract}
The purpose of this research is describe and analyze the implementation process of agricultural development policy for agropolitan corn programs in terms of its legal basis, bureaucratic planning, and performance in Gorontalo province. This research type is qualitatif with using of naturalistic method. The findingsof this research are; 1). Agricultural development policies for corn agropolitanprogram as the leading program in its execution has got support from the Government of Gorontalo beginning with the establishment of the Department of agriculture and food security as executor; 2).To improve the performance of the bureaucracy, government provide incentives in the form of regional performance allowances (TKD), provision of agricultural technology (Alsintan, seeds, fertilizers, medicines and agropolitan task force as an escort for farmers started land preparation to post-harvest; 3). Corn agropolitan program hasn't been able to increase the farmers ' income, meaning that it has not fully enjoyed by farmers, especially farmers who have a narrow land (less than one hectare).
\end{abstract}

Keywords: Agricultural Development Policy, Farmers Revenue

\section{Introdution}

Today, new paradigm development is focused on distribution and public participation begins with enactment act no 221999 that has been fine-tuned on act no $32 / 2004$ about local government. In the presidential regulation no.7 / 2005 on national medium term development plan (RPJMN) year 2004-2009, there are five program revitalization agriculture that has been performed by the government namely: (1) Increasing food security; (2) the development of agribusiness; (3) increasing the agriculturist prosperity; (4) fisheries resources development; (5) enhancement of the utilization of fishery resources (Arifin, 2007)

In the medium term development plan (RPMJ) 2001-2006 and continued RPJ M 2007-2011 has been set three priorities: development economics, education, and health. On the economic development of the agricultural sector is represented by the particular corn agropolitanprogram, reason being it is widespread among the community of farmers, the land available is extensive, it is supported by the technology of agricultural tools, seeds and fertilizer. In addition, corn is also the sector that at most accommodateof labor, short-lived, so economically more profitable farmers.

Based on some those reasons, then the agricultural development corn agropolitan program got very good response from the farming community. This can be seen in the interest of farmers to replant corn that is widespread in Gorontalo province so that corn production increased from 2-3 tons per hectare to be 4-6 tons per hectare. The success in increasing production of corn and corn export to various neighbouring countries such as Singgapura and Malaysia made the province of Gorontaloknown in Indonesia even internationally. Not only that, at 2012 Gorontalo province had been believed to be the first international seminar of corn that was attended by various corn-producing countries of the world.

The success achieved was not perceived by the farming community especially for corn farmerswho have a narrow land (less than one hectare). Several supporting facilities such as seed corn agropolitan programs, fertilizer, agricultural implements as well as bank credit is only enjoyed by farmers who have a large land (more than two hectares). Otherthings such as scarcity of maize seed, fertilizer, drugs on the planting season and a low price of corn at the harvest season so much enjoy the fruits of an increase in maize production was extensive and farmers who are employers of corn while corn growers are narrower still in poor condition. It means corn agropolitan program has brought the province of Gorontalo became famous in Indonesia and internationally has not contributed in increasing farmers' income and welfare.

\section{Methods}

This research using a qualitative approach with naturalistic methods (Sugiyono, 2008). The focus of this research is; 1). Identify the process of agricultural development policy in corn agropolitanprogram include the legal basis for execution work programs, and the results. 2). The impact of agricultural development policy against the government, businessmen, corn agropolitanand agriculturist community program (increase in production, an increase in income and welfare of the family farmer). 
The research is provincial gorontalo. Data obtained from any informen through (1). Interview, (2).A book record, (3).the voice recoreder. Beside from an informer, the data also obtained from several documents and events in accordance with the focus of research. The techniques that used is analysis of interactive model analysis consisting of three components analysis namely of reduction data, cereal offering data and conclusion (Miles danHuberman, 1992)

\subsection{Profile of Gorontalo}

\section{Results and Conclusion}

Gorontalo province is one of the 33 provinces in Indonesia. Gorontalo is an enlargement province of North Sulawesi, established pursuant to law No. 39 of 2000 and officially established on February 16, 2001. Broad its territory is $12.215,44 \mathrm{~km} 2(1.221 .544 \mathrm{Ha})$ or $64 \%$ of Indonesia. Geographically gorontalo situated between $0,19^{\prime}-0,15^{\prime}$ south latitude and 120,23 ' $-123,43^{\prime}$ east longitude. Gorontaloconsisting of 5 (five) regency namely regency gorontalo, bone bolango, pohuato, north gorontalo and gorontalo city. BPS Data 2011 showed that the population of Gorontalo province is 1.038,585 consisting of men is 520.885 and women is 517.700. The official statistics gorontalo 2009, that the number of poor people in 2007 is about 241.900 or $27,35 \%$ of total population, in march 2008 as many as 221.623. In March 2009 of poor people is 224,617 that means there's an increase in number of poor people as much as 2.994 people by 2009 . This poor population fluctuation is caused by poor farmers in Gorontalo. Poverty happens farmer level caused by the price is still low due to the factor of infrastructure (roads, broken bridges) and a price controlled by collectors. This phenomenon caused the farmers have yet to gain significant benefits from the increase in maize production.

\subsection{Legal basis of agropolitan program}

Enactment act no 32 / 2004 regional government has changed paradigm of public services system and management development. Based on presidential no. 20/2004 on government working plans (RKP) in achieving national development goal: 1). Creating safe and peace indonesia, 2). Manifesting indonesia equal and democratic; and 3 ). Improve the welfare of indonesian people.

To realize that, the government of gorontalo has drawing up regional middle term development plans (RPJMD) 2007 - 2012. The RPJMD for period 2007 - 2012 based on vision "gorontalo as innovation province and mission build gorontalo an independent, productive and religious, then has set a plan agricultural development as the main source of revenue (PAD).

Department of agriculture and food security of gorontalo province in help make agricultural developments assign vision "realization of agricultural people of being formidable, culturedentrepreneur through the agropolitanprogram and agribusiness approach that environmentally and local independence oriented.

Based on the vision, department of agriculture and food security set its mission as follows: 1). Growing up the spirit of entrepreneurship agricultural for people gorontalo civilized entrepreneur. 2). To realize agricultural development through growth and development of agropolitan zone based on corn. 3). Steadying the support system which includes natural resources, human resources technology, institutional, and facilities. 4). To realize food security tough, through the program of sustainable agricultural development and environmentally ("Gorontalo" The Agropolitan, 2005).

The main reason underlying the agropolitan corn program is supporting by potential of land resource is $483.649 \mathrm{Ha}$ or $37 \%$ of the total area, it's about 123.708 of households gorontalo residents livelihoods are sourced from the agricultural sector and the GDP contribution (about 30\%) (Department of agriculture and food security Gorontalo, 2010).

Based on the regulation of agriculture minister no.273/KPTS/OT.160/4/2007 on guidelines for training institutional of husbandman. Then for the mean the local administration unveiled regional regulation no. 07 / 2009 about the formation of organization and work procedures of the coordination board of agricultural information, fishery, and forestry in provincial level, district/city, sub-district, up to the levels villages a whole of gorontalo province.

This body has a duty to provide technical support, administrative and oporasional in the fields of agricultural information, fishery and forestry (article 4 ). In article 5 is mentioned that the function of this body is: a). Implementation planning to arrange the coordination in the field of agricultural information, fishery and forestry; b). formulation of technical policy in agricultural information, fishery and forestry; c). Preparation of training programs for more professional career counselors in carrying out tasks; d ). Formulation of the assistance program to strengthen independence, leading perpetrator of self-supporting and entrepreneurship and business doers that tougher facing global market; e). Programs established monitoring and evaluation in the fields of agricultural information, fishery and forestry. 
To support the activities in the field of funding both for the distribution of government fund and to meet the needs of the farmer's needs by the government involves some financial institutions such as Bank Rakyat Indonesia (BRI), Bank Mandiri and BNI 46 Banks.

Based on the above description it can be concluded that in terms of the policy theory that the process of agricultural development corn agropolitan program in terms of planning have been appropriate because it has been supported by rational consideration of the available land area data, cultural communities and economically transformed maize more profitable due to the time it takes to achieve at the final result of about 100 days.

The development of corn agropolitan in gorontalo a period of 2006 - 2009 as follows: production of corn of 2006 at 416,222 tons with a broad harvest 109,792. In 2007, production increased to 572,784 tons with broad harvest 119,027 hectares. Then in 2008,production increased to 752,727 tons and in 2009 is 569.110 tons dry corn, decline $24.48 \%$ compared with production of corn in 2008 .

The decline caused by decreasing harvest area of 31.638 hectares $(20.22 \%)$ and productivity of 2.57 a quintal/hectares. Production of corn in 2010 is 582 tons dry corn, increased $2.43 \%$ compared 2009. Increase production is caused by an increase in harvest area 5.707 hectares $(4.57 \%)$. But productivity decreased by 0.93 a quintal/ha (2.04\%). (Official news statistics no. 169 / $07 / 75$ / 2010 ).

The results of the realization of corn agropolitaan program in 2009 is target 569.110 tons from 812.000 tons with the achievement of the performance of $70,09 \%$. Productivity corn per hectare is 45,60 quintal $(4,56$ ton/ha ), while target productivity of corn in 2009 is 55,20 quintal/ha so that the achievement of performance was $82,61 \%$. Not achieve the production target caused by declining of harvest area and long dry season.

According to farmers, on the other side, the decline is more caused by growing season which is not appropriate because scarcity of seeds, fertilizer and medicinal on growing season.

To protect farmers from the game of the price of a merchant as well as providing a big profit to farmers, then the governor to make a decision no. 119/ 2006 about the selling price of corn in the gorontalo. Associated with it, farmers following statement:

"It seems to me as chairman of the respect by the presence of the Governor of Gorontalo Decree No. 119 of 2006 which is a refinement of the previous regulation is a very rational decision because it is in favour of the farmers and I support it because the policy issued a decision very profitable farmers in general and can increase our revenue, but in reality the price level, the farmer does not comply with published rates the Government through electronic media" (Interview with Chairman Of Dulupi Village Farmers Group, 15 Maret 2012 )

By the analysis of secondary data and the results of an interview as described above, it is concluded that act no 32 / 2004 has been used as the basis of government management in creating good governance, involving the government the private sector and social norms and was a confirmation strategic bureaucracy in the arrangement of government toward a system of management of public services more flexible, accountable and more oriented in the interests of the public

The farmers is the main target in corn agropolitan program to raise revenue and welfare and reducing poverty rate. In 2005 poverty $29.15 \%$ (255.000), increased to $29.13 \%$ ( 273.800 ) in 2006 , increasing by 0,08 $\%$, in 2007 poverty decreased to $27.35 \%$ ( 241.900$)$, in 2008 poverty declining more be $24.88 \%$ ( 221,617 ), in 2009 poverty rising again into being $25.01 \%$ ( 224.652 ) raise about 0.13 digits, and in 2010 descend again be 23,19 (209,886) (BPMD-PK of gorontalo province 2011).

Of the data and some of the farmers' statement can be explained that the program has improved the corn agropolitan production and farmers' income. The increase in revenue has made the farmers were able to meet the necessities of life such as finance his son's education. But it still can not be a guarantee for farmers to live in sufficiency, because climate disruptions and rising prices of necessities of life (inflation) is a threat to return is unlikely to meet the necessities of life (poor) especially for those farmers who have narrow land.

What was presented above indicating that the principle of good governance which includes: Partisipation, Role of law, Tranparancy, Responsiviness, Consensus, Equity, Effectiveness and efficiency, Accontability, Stategic Vision, should be addressed in the policy of Interrelated agricultural development corn agropolitan program but in reality it has not been able to increase farmers' income and the reduction of poverty. This caused coordination among stekholders not running as expected because it is still egosectoral.

Ideally, the public policy is a continuous process, therefore it's the most important thing is the policy cycle. The cycle includes policy formulation, implementation and evaluation of policies (Nakamura \& Smallwood, 1980; Parsons, 1997; Mohammad, 2008). The policy that has been formulated to accomplish a particular objective. In this context is understandable if Lineberry (1978) argue that the policy will not succeed if in the implementation has no relationship with its intended purpose.

The formulation of a policy that is created will not be mean or just be a series of beautiful words and raw stored neatly in a document if it is not implemented. Therefore, the implementation of policies need to be situational, honest, is referring to the spirit of empowerment and insightful competence (Solichin, 1999). In 
order to implement the policy really is a process of interaction between setting goals with action to achieve the desired impact(Pressman dan Wildavsky in Parsons, 1997).

\subsection{Implementation and evaluation of agricultural development policy for corn agropolitan program.}

The implementation of the policy according to lineberry in nawawi ( 2009 ) that policy implementation encompasses those actions by public and private individuals (and groups) that are directed at theachievement of goals and objectives set forth in prior policy decisions.This statements assign a meaning that the implementation of the policy is the actions carried out by the individuals rather than And groups, the government and private that is directed at accomplishment of an objective and target's priority in the resolution policy.

Policy implementation behold are being considered since this policy in formulating and implementing process. Implementation policy is a stage cycle in public policy. This stage draws implementation process of a policy itself. All government policy that no meaning, if the implementation of policies is done through road appropriate and as is on public interests ( soenarko, 2005).Palumboin islamy( 2003 ) said that stage of implementation phase policy is very important to see if a policy that could go well or not. Of both opinion, good palumbo and seonarko see that phase implementation policy very important to be implemented.

The implementation of such a policy are not confined to the ranks of the bureaucracy, but also involves actors outside government bureaucracies, such as community organizations, and even individuals as well as policy implementation. To avoid any conflict or difference of perception in the execution of an implementer (unit and non bureaucratic), the administrative process should always be based on a standard operational procedure (SOP) as a reference implementation.

Mazmaniansabatier ( 1983 ) and said that discusses implementation problems policy means trying to understand what happened actually when program enacted, expressed or formulated the activities and events occurring after ratification process policy good concerning efforts to engender mengadministrasikannya and real impact on events in society or particular.

\subsection{Corn agropolitangorontalo program.}

Agropolitan derived from the word agro which means agriculture and politan which means city that can be defined as the city of a farm or city in the agriculture or farming in the area of city (friedman and douglas, 1975). Completely, agropolitan is a city of a farm that is grown and developed as a function of the system and, agribusiness capable of serving business push, exciting, and took the activities of agricultural development (agribusiness) the surrounding region (suwandi, 2005).

Wibowo (2004) explains that the concept agropolitanwas first introduced by Mc. Douglass and Friedmann in 1975 as a strategy for rural development. Basically, this concept provide services in urban or rural area with other terms used by Friedmann is "lea in town". Thus farmers or villagers do not need to go into town to get the service, both in the service that deals with the problem of production and marketing as well as with issues related to social and cultural needs in daily life for farmers.

The management of the institutional bureaucracy in improving the performance of the public bureaucracy policy become the strategic issue. It is caused that improving performances bureaucracy have a broad implication in life "economic and political" (Dwiyanto, 2006 ). In the economic, repair the performance of the bureaucracy could improve investment climate which is very required in economic development to get out of a prolonged crisis.

The bad bureaucracy performance public in indonesia often the most important factor of lower interest invest for entrepreneurs. Unfortunately, performance of public bureaucracy in indonesia based on the study and the observation not widely undergo a change, even cederung growing worse, so government difficult attract investors to invest, plus the legal uncertainty and security nasionalyang certainly would hinder efforts this people for immediate out of economic crisis and poverty of its people.

Agricultural development policy for corn agropolitan program as the government's leading program in Gorontalo, so institutional strengthening (both in terms of the norms as well as the improvement of the organizational structure) as one form of bureaucratic reform should be done in an effort to setting up bureaucracy and bureaucratic performance improvements to public services. Bureaucratic reform essentially rests on the performance improvement efforts in order to increase the productivity of both the Central Government and organizations in the region (Turner \&Hulme, 1997).

Agricultural development policy is one of the ways taken by Central and local governments in the provision of employment, increased social welfare, elimination of poverty, the provision of food production, export earnings in foreign exchange. Given the enormous role in economic development and improvement of welfare community, the government gave spirit and motivation to all local governments to make this sector as the leading sector. 
The public bureaucracy at the level of local governance that works to provide the best service to the community is currently largely co-opted by attitudes and behaviors that respect vested interest. As a result, is the low level of aksebilitas and quality of public services that reflected through the performance accountability of public bureaucracies in a variety of public service management.

The low level of performance had led to a variety of resistance and poor actions like demonstrations and this will lower the legitimacy of Government. The inability of the public in using bureaucratic tasks and functions optimally with respect to public services among other things caused by factors such as a lack of capability, competency, professionalism and mostly bureaucratic officials (Tjokrowinoto, 2001).

\subsection{Performance of bureaucracy of corn agropolitan program.}

To encourage the performance of local government bureaucracy has imposed a system of performancebased incentives. It is one of the efforts made by local governments in encouraging better performance in the public service. Performance-based incentive system, there was in the form of regional performance allowances (TKD) and is an effective instrument for improving the performance of employees in practice known as performance-based payroll system (SPBK).

However, the most popular applied is the provision of bonuses and the determination of the amount of salary based on assessment who compares the performance of employees in an individual manner and kolompok met the target has been set up by an organization. That means that one of the elements of good governance been implemented in program agropolitan and doctrine is very concerned with another(Mahmudi, 2007).

Dwiyanto (2006) states that improving the performance of public bureaucracies into a strategic policy issues because of bureaucratic performance improvement has implications in the economic and political life. To improve the performance of the bureaucracy, particularly for employees as government officials, if seen in terms of the principle of public administration in fact cannot be separated from the question of human beings who live in the organization. As for the bureaucratic organization of human resources have features that address the dynamics, properties and behaviors and motivations of different work. Therefore, when the public administarsi is not dynamic nor push towards progress, then people will quickly turn and less respect for him (Puluhulawa, 2011).

Observe the elements of good governancepresented by the experts mentioned above, then the incentive system to enhance the performance of the bureaucracy as well as businessmen as farmers is one form of government gorontalo innovation. Forms of incentives that are applied in the private is adopted by local authorities to apply to the public sector especially in the Government bureaucracy in the agricultural development policy program agropolitan corn. In an effort to do that is energizing a movement to build employee motivation to perform well in the success of the program is to increase production of maize agropolitan, farmers ' income and their families to escape poverty.

To empower the bureaucracy of local government, the private sector advances have inspired the public sector to apply the techniques used in the private sector through New Public Management (NPM) movement to public sector bureaucracy is more powerful. So this system of incentives given to employees who perform well will get additional income in form of regional performance allowances (TKD) according to the results of the relevant achievements and paid each month along with new monthly salary payments (Muhammad, 2008).

Improving performances bureaucracy with incentives have motivate employees to work in accordance with the main task of and functions (Tupoksi) so that it has given a positive impact in policy on agricultural development for corn agropolitan program as seen from a program that is executed has reached its target ( about $97 \%$ ) in accordance with the purpose of this policy, as an increase in productivity, an increase in GDP, increasing farmers' income, work force absorption and decrease in poverty rate of society.

Tiebout (1957), Isard (1966), and Nuses (1968) in Rusastra et al., (2002,23) states that that at least three conditions necessary in optimizing agropolitan program implementation. The third requirement is: "1). Must be kept to the local autonomy and authority for natural resource management to make gone development sustainable globalization; 2). Alarger part of the profits derived from activities agropolitan must be invested in order to improve its results and push subsequent economic growth; and, 3). Minimum and maximum limits for the land area belongs to be determined, so that natural resources can be managed in a rational and productive".

The target of agropolitan development area is to develop agricultural area is potentially agropolitan area, (1). Communityempowerment of an offender agribusiness; (2).Institution strengthening institutional system farmers and development of agribusiness; (3). The development of institutional counseling integrated development; (4). The development of conducive climate for investment and business (Wibowo, 2004).

The success of the program agropolitan area development indicators are adapted to local conditions can be seen from an impact and output produced as follows; (1). Society wage increased $5 \%$, productivity increase at least $5 \%$, public saving rose by at least $10 \%$. (2). Output: the long term projects $70 \%$ may be conducted, 80 $\%$ of the institutional peasantry could extrude business oriented market and the environment, participative 
planning and agreed upon with implementation, business network husbandman formed and active, multi discipline and professional team formed and operational, $80 \%$ of contact peasantry / husbandman "maju" capable of being place learn to farmers surrounding it.

Innovation policy of gorontalo government is known with 9 basic of agropolitan, namely;(1). Provision of tools and machinery agriculture. (2). Provision of fundfor guarantees husbandman. (3). Provision of seed preëminent; fertilizer and control pests/disease. (4). Streamlineof marketing and price guarantee. (5). The development or providing of irrigation and road of access agropolitan. (6). Pilot/show window in every region of agropolitanand agropolitanposts (7). An increase of agriculture resources, (8). Increase the effectiveness or the role of maize center, and (9). Planning and coordination(GorontaloThe Agropolitan, 2006).

To support of corn agropolitan program then the government pursue the facilities to support safeguard agricultural development is;1). Access roads (farm roads); 2.)agricultural machine tools; 3), Quarry; 4). Institute of technology experts and extension workers; 5). Means of production outlet; and 6 Marketing (Mohammad, 2007).

\subsection{Conclusion.}

\section{Conclusion and suggestion}

1. A policy of agricultural development for corn agropolitanprogram as priority programs have received support from the government gorontalo through regulation the formation of dept. of agriculture and food security as the executor of work programs, improving the performance of the bureaucracy by providing incentives keputusan performance allowance (TKD), as the motivation for the employees the provision of agricultural technology (Alsintan, preëminent seeds; fertilizer, drugs and the task force agropolitan as a companion to farmers both in planning and after harvest.

2. Improving performance employees have been able to motivate farmers to receive agricultural technology and thus hope to increase productivity of corn to reality every year

3. Increased productivity of corn and farmers' income has pushed economic growth, reduction of unemployment and reducing poverty

4. Theutilization of agricultural technology has not been fully enjoyed by farmers is mainly farmers whose land is narrow (one hectare to the bottom).

5. Lackof farmer access to financial institutions

6. The utilization of institutional husbandman still limited function of coordination to get help from the government, as a fertilizer, preëminent seeds and medicines though yet a good run while in the activities of capital unable

7. Partiesmore enjoys the profits was the government, traders, merchant and exporters

\subsection{Suggestion}

1. Theneed for a policy review is being undertaken now to improve alignments to smallholder farmers especially those away from government services such as the provision of land to farmers at least twoacres each farmer, the provision of working capital and take advantage of farmers ' agricultural extension workers and respect for an active season in addition to accompany farmers or post-harvest.

2. Anisolated area for transportation must immediately be addressed.

3. Improve the function of supervision and coordination between related services department.

\section{Referrence}

[1] Arifin, Bustamin. 2007. Diagnosis Ekonomi Politik Pangan dan Pertanian. PenerbitPT. Grafindo Persada. Jakarta.

[2] Sugiyono. 2008. MetodePenelitianBisnis. Bandung: Alfabeta

[3] Milles, M.B. Huberman, A. M..1992. Qualitative Data Analysis. (Terjemahan). Translated by TjetjepRohendiRohidi. Analisis Data Kualitatif. Universitas Indonesia, Jakarta.

[4] Parsons, Wayne. 1997. Public Pulicy: An Introduction to the Theory and Practiceof Policy Analysis, Edward Elgar Publishing, Inc. Cambridge.

[5] Solichin, Abdul Wahab. 1997. Analisis Kebijaksanaan: Dari Formulasi Implementasi Kebijakan Negara. Bumi Aksara. Jakarta.

[6] Badan Deptan. 2002. General Guidelines of agropolitanarea developmentandGuidelines of Pilot agropolitanprogramregion for agriculturalHumanResourceDevelopment, Department of Agriculture. Jakarta.

[7] Dwiyanto, Agus. 2006. ReformasiBirokrasiPublik di Indonesia. Gajah Mada University Press. Yokyakarta.

[8] Dun, William. 2004. Pengantar AnalisisKebijakanPublik. Yokyakarta: Gajah Mada University Press.

[9] Friedmann, J, M. Douglass. 1975. Agropolitan Development: Towards a New Strategy for Regional Development in Asia.Paper presented in United Nations Centre for Regional Development. Nagoya, November 1975.

[10] $5^{\text {th }}$ of Gorontalo Agropolitan. 2007. Dinas Pertanian Dan KP Propinsi Gorontalo

[11] Mazmanian, Daniel Adan Sabatier, Paul A.. 1983. Implementation and PublicPolicy, Scot, Foresmen and Company, California.

[12] Muhammad, Fadel. 2007. Reformasi Birokrasi Pemerintah ProvinsiGorontalo, Power Point, disampaikan pada Workshop Best Practices Reformasi Birokrasi.

[13] Indonesian Government RegulationNo..8Year 2003on Guidelines forthe regional organization

[14] Gupta, Ranjit.2003.Note on Institution Building. Oxford and IBH Publishing House, New Delhi. 
[15] Hutahean, Marlan. 2004. Institutional Up grading, Paradigm Change and PolicyChoice as Strategies of Alleviating Poverty; "PublicAdministrationPerpective".Economic and Finacial Management Worskhop. Asia Development Bank andNetwork of Asia - Pasific Schools and Institutes of Public Adminstration and Governance ( NAPSIPAG) Kuala Lumpur, Malaysia.

[16] Grieco, M. 1990. Development in the Developed World: Revealing and the Hidden Agenda in Rural Development : Problems and Practices (Editors : H. Buller and Wright, S.). Athenaeum Press Ltd. Great Britain.

[17] Aggrawal, J. 2002. Training Method for Community Development in India. Country Paperin the Asian Productivity Organization Seminar. Held in the Republic of Korea. Asian Productivity Organization. Tokyo.

[18] Cranton, Patricia.2001. Interpretive and Critical Evaluation.New Directions for Teaching and Learning Journal. No. 88, Winter: John Wiley \& Sons, Inc 